\title{
Depression as a Glial-Based Synaptic Dysfunction
}

\author{
Daniel Rial ${ }^{1,2}$, Cristina Lemos ${ }^{1}$, Helena Pinheiro ${ }^{1}$, Joana M. Duarte ${ }^{1}$, \\ Francisco Q. Gonçalves ${ }^{1}$, Joana I. Real ${ }^{1}$, Rui D. Prediger ${ }^{2}$, Nélio Gonçalves ${ }^{1}$, \\ Catarina A. Gomes ${ }^{1,3}$, Paula M. Canas ${ }^{1}$, Paula Agostinho ${ }^{1,3}$ and Rodrigo A. Cunha ${ }^{1,3 *}$ \\ ${ }^{1}$ CNC - Center for Neuroscience and Cell Biology, University of Coimbra, Coimbra, Portugal, ${ }^{2}$ Departamento de \\ Farmacologia, Universidade Federal de Santa Catarina, Florianópolis, SC, Brazil, ${ }^{3}$ Faculty of Medicine, University of Coimbra, \\ Coimbra, Portugal
}

\section{OPEN ACCESS}

Edited by:

Tycho M. Hoogland, Erasmus MC, Netherlands

Reviewed by: Lisa Mapelli, University of Pavia, Italy Anna Maria Pugliese University of Florence, Italy

*Correspondence: Rodrigo A. Cunha cunharod@gmail.com

Received: 11 November 2015 Accepted: 27 December 2015 Published: 22 January 2016

Citation: Rial D, Lemos $C$, Pinheiro $H$ Duarte JM, Gonçalves FQ, Real J, Prediger RD, Gonçalves $N$ Gomes CA, Canas PM, Agostinho P and Cunha RA (2016) Depression as a Glial-Based Synaptic Dysfunction. Front. Cell. Neurosci. 9:521. doi: 10.3389/fncel.2015.00521
Recent studies combining pharmacological, behavioral, electrophysiological and molecular approaches indicate that depression results from maladaptive neuroplastic processes occurring in defined frontolimbic circuits responsible for emotional processing such as the prefrontal cortex, hippocampus, amygdala and ventral striatum. However, the exact mechanisms controlling synaptic plasticity that are disrupted to trigger depressive conditions have not been elucidated. Since glial cells (astrocytes and microglia) tightly and dynamically interact with synapses, engaging a bi-directional communication critical for the processing of synaptic information, we now revisit the role of glial cells in the etiology of depression focusing on a dysfunction of the "quad-partite" synapse. This interest is supported by the observations that depressive-like conditions are associated with a decreased density and hypofunction of astrocytes and with an increased microglia "activation" in frontolimbic regions, which is expected to contribute for the synaptic dysfunction present in depression. Furthermore, the traditional culprits of depression (glucocorticoids, biogenic amines, brain-derived neurotrophic factor, BDNF) affect glia functioning, whereas antidepressant treatments (serotoninselective reuptake inhibitors, SSRIs, electroshocks, deep brain stimulation) recover glia functioning. In this context of a quad-partite synapse, systems modulating glia-synapse bidirectional communication - such as the purinergic neuromodulation system operated by adenosine $5^{\prime}$-triphosphate (ATP) and adenosine-emerge as promising candidates to "re-normalize" synaptic function by combining direct synaptic effects with an ability to also control astrocyte and microglia function. This proposed triple action of purines to control aberrant synaptic function illustrates the rationale to consider the interference with glia dysfunction as a mechanism of action driving the design of future pharmacological tools to manage depression.

Keywords: depression, synapse, astrocytes, microglia, purines

\section{INTRODUCTION}

Depression is the neuropsychiatric disorder with higher incidence worldwide, representing a major socio-economical burden (Kessler et al., 2003). Depressive conditions display heterogeneous presentations and are defined clinically based on different affective symptoms (sadness, desperation, apathy, anhedonia, sensation of discomfort) that decrease interest in daily 
activities (Ferrari et al., 2013). Understanding the causes and neurobiological basis of depression remains a challenge, probably due to the lack of faithful animal models (Berton et al., 2012). The relation between cumulative stress and the incidence of depression (de Kloet et al., 2005) and the prevalence of depression in suicide completers (Coryell and Young, 2005), provide two windows of opportunities to indirectly study the neurobiological basis of depression using chronically stressed animals and brain samples from suicide completers.

\section{PURPORTED BIOLOGICAL BASIS OF DEPRESSION}

Depressive conditions have traditionally been considered to involve a deregulated hypothalamic-pituitary-adrenal (HPA) axis, leading to an aberrant impact of sustained increased levels of glucocorticoids (Sousa et al., 2008). However, recent studies in adrenalectomized animals (thus blunting the main source of glucocorticoids) revealed an impact of ghrelin rather than glucocorticoids in formatting the emotional disturbances associated with repeated stress (Meyer et al., 2014).

Another lead for the neurobiology of depression is based on the clinical use of serotonin-selective reuptake inhibitors (SSRIs) and tricyclic antidepressants (TCAs) to manage depression, which hints at the dysfunction of the neuromodulation by serotonin and other biogenic amines in depression (Krishnan and Nestler, 2008). However, these drugs have a slow onset of action (over 2 weeks) and are effective in only circa $50 \%$ of patients, leaving open the possibility that they may influence different targets apart normalizing the levels of biogenic amines.

Neurotrophins and in particular brain-derived neurotrophic factor (BDNF) have also been linked to depression, based on the ability of BDNF to reactivate neuronal plasticity and on the association between serum BDNF levels and depression (Castrén, 2014). This should be cautiously evaluated since the plasma levels of substances might not reflect their brain levels and there is no clear association between depression and different polymorphisms of the bdnf gene (Gyekis et al., 2013). Also, excessive BDNF-induced plasticity can actually trigger an aberrant hyper-plasticity, as heralded by the key pathogenic role of BDNF in neuropathic pain (Trang et al., 2012).

\section{SYNAPTIC DYSFUNCTION IN DEPRESSION}

A major breakthrough in understanding depression was the observation that sub-anesthetic doses of ketamine, an NMDA receptor antagonist, can revert rapidly (within $90 \mathrm{~min}$ ) symptoms of depression, with a long-lasting antidepressant effect (2 weeks; Berman et al., 2000; Zarate et al., 2006). Since NMDA receptors are the main switches to trigger synaptic plasticity (both longterm potentiation, LTP, and depression, LTD), this indicates that an abnormal plasticity at glutamatergic synapses underlies the expression of depressive symptoms (Duman and Aghajanian, 2012); indeed, chronically-stressed rodents display abnormal patterns of synaptic plasticity (both LTP and/or LTD) in brain areas involved in emotional processing, namely amygdala, ventral striatum, hippocampus and prefrontal cortex (Krishnan and Nestler, 2008). Animal studies also allowed identifying the molecular mechanisms of the antidepressant effect of ketamine, which involves the antagonism of NMDA (2B) receptors and the preservation of dendritic morphology and AMPA receptor trafficking through an mTOR pathway in the prefrontal cortex (Li et al., 2010). This joins other observations showing that riluzole and antagonists of types $2 / 3$ or 5 metabotropic glutamate receptors, which control glutamatergic transmission, also display robust antidepressant effects (Machado-Vieira et al., 2009; Pilc et al., 2013). Altogether these observations support the hypothesis that depression results from the disruption of mechanisms controlling synaptic plasticity in afflicted regions (Duman and Aghajanian, 2012).

This de-regulation seems to translate into a destabilization and loss of synaptic connections. Indeed, repeated stress triggers a reduction of dendritic complexity in prefrontocortical and hippocampal neurons (Magariños et al., 1997; Sousa et al., 2000; Radley et al., 2006) and a selective loss of markers of excitatory synapses (Gilabert-Juan et al., 2012; Tzanoulinou et al., 2014; Kaster et al., 2015), which recover upon alleviation of "depressive"-like symptoms using SSRIs, exercise or enriched environment (Li et al., 2010, 2011; McEwen et al., 2012). Postmortem brain samples of depressed patients also revealed a reduction in the size rather than number of prefrontocortical and hippocampal pyramidal neurons (Rajkowska et al., 1999; Stockmeier et al., 2004) accompanied by a decreased number of synaptic contacts (Kang et al., 2012). As occurs in stressed rodents, synaptic markers in frontolimbic area are also altered in patients with major depressive disorder (Feyissa et al., 2009; Zhao et al., 2012; Duric et al., 2013).

This pivotal role of the disruption of mechanisms controlling synaptic plasticity for the expression of depressive symptoms also has the attractive feature to allow bridging the different traditional explanations for the emergence of depression. In fact, glucocorticoids are well established to affect synaptic plasticity and to contribute for synaptic atrophy in several brain regions (Sousa et al., 2008). Likewise, BDNF is well recognized as a bolster of synaptic plasticity (Gray et al., 2013) and different biogenic amines, such as serotonin (Lesch and Waider, 2012), noradrenaline (Marzo et al., 2009) and dopamine (Tritsch and Sabatini, 2012) impact on synaptic plasticity in cortical regions.

However, although the pivotal role of aberrant synaptic plasticity successfully integrates different findings derived from patients and animal models of depression, it still fails to provide an explanation for the etiology of depression. This review proposes to focus on the emerging concept of the quad-partite synapse (Schafer et al., 2013), integrating both astrocytes and microglia as critical pillars of synaptic plasticity, to address the possible relevance of a mis-communication between glia and synapses, as a possible basis of depression.

\section{THE "QUAD-PARTITE” SYNAPSE}

Astrocytes were long considered as morphological and metabolic support cells, as testified by their importance in the synthesis 
(Rose et al., 2013) and re-uptake of glutamate (Asztely et al., 1997; Arnth-Jensen et al., 2002), in buffering extracellular $\mathrm{K}^{+}$to control neuronal excitability (Wallraff et al., 2006), in neurovascular coupling (Viswanathan and Freeman, 2007; Petzold et al., 2008; Figley and Stroman, 2011) and transport (Rouach et al., 2008) and delivery of nutrients to active synapses (Magistretti et al., 1999; Pellerin et al., 2007). This concept has actually evolved to recognize astrocytes as dynamic players engaged in a bi-directional communication with synapses and able to actually format synaptic function with impact on the expression of behavior (Achour and Pascual, 2010; Allen, 2014; Oliveira et al., 2015). This interplay between synapses and astrocytes is so tight that it is difficult to disentangle if a synaptic dysfunction results from intrinsic modifications of neurons or from astrocytic modifications (Agostinho et al., 2010; Sanacora and Banasr, 2013; Crunelli et al., 2015; Verkhratsky et al., 2015).

Probably the first experimental support of an ability of astrocytes to respond to synaptic activity was provided by observations that astrocytes respond to glutamate by triggering a directional long-distance response, typified by a wave of variation of intracellular calcium (Cornell-Bell et al., 1990). The inter-astrocytic transport of calcium waves is possible thanks to the organized formation of a syncytium through different connexins pores, that form an alphabet still to be fully deciphered to understand this long-range directional communication of information through astrocytes (Wallraff et al., 2004; Theis and Giaume, 2012; Decrock et al., 2015). Astrocytes respond not only to glutamate, but to most neurotransmitters and neuromodulators, such as GABA, noradrenaline, acetylcholine or adenosine 5'-triphosphate (ATP; Volterra and Meldolesi, 2005; Haydon and Carmignoto, 2006). Astrocytic calcium waves can feedback to influence neuronal responses (Nedergaard, 1994; Parpura et al., 1994) and control synaptic strength (Jourdain et al., 2007; Perea and Araque, 2007) through the release of different mediators such as glutamate, ATP, D-serine, NO, neurotrophins, prostaglandins or cytokines to name a few (Volterra and Meldolesi, 2005; Haydon and Carmignoto, 2006). Several of these mediators are released from astrocytes in a vesicular manner, with SNARE complexes similar, but with some differences to neurons (e.g., synaptobrevin 2), able to sustain a quantal release (Bezzi et al., 2004; Pangrsic et al., 2007). The relevance of this astrocytic vesicular apparatus to control synaptic function is re-enforced by the observation that astrocytic processes enwrap synapses in a spatially organized manner, with a single astrocyte wrapping from 300 (in rodents) up to 90,000 (in humans) synapses (Bushong et al., 2002; Ogata and Kosaka, 2002; Oberheim et al., 2006) and this association of astrocytes with synapses was found to be an experiencedependent dynamic process (Genoud et al., 2006; Haber et al., 2006). This prompted the concept of the tri-partite synapse to recognize the importance of the astrocytic network as a new level of integration of information in neuronal networks (Araque et al., 1999, 2014; Halassa et al., 2007). Accordingly, synaptic plasticity processes are controlled by different gliotransmitters such as D-serine (Yang et al., 2003; Panatier et al., 2006; Henneberger et al., 2010), glutamate (Fellin et al., 2004),
ATP (Koizumi et al., 2003; Zhang et al., 2003; Pankratov and Lalo, 2015) or adenosine (Newman, 2003; Pascual et al., 2005; Serrano et al., 2006) or by controlling glutamate clearance (Diamond, 2001; Tsvetkov et al., 2004; Omrani et al., 2009; Murphy-Royal et al., 2015). Accordingly, astrocytic function critically affects integrated brain responses such as sleep, mood or memory (Banasr and Duman, 2008; Halassa et al., 2009; Suzuki et al., 2011; Lima et al., 2014; Perea et al., 2014; Matos et al., 2015).

The addition of microglia to the number of synaptic players is more recent. Microglia coordinate brain innate immunity, displaying features characteristic of immune cells able to rapidly expand their population, to chemotaxically migrate to sites of injury and to trigger and sustain inflammatory responses through their chemokine and cytokine repertoire (Lynch, 2009; Kettenmann et al., 2011). Traditionally, microglia were considered to be "resting", becoming "activated" upon allostatic changes to coordinate immune-like responses (Perry and Gordon, 1988). Several studies revealed that the purported "resting"-state of microglia actually corresponds to an active surveying state, where microglia phylopodia dynamically interact with neurons and astrocytes with a regulatory and supportive role critical for brain homeostasis (Raivich, 2005; Hanisch and Kettenmann, 2007; Wake et al., 2013; Cherry et al., 2014). In particular, microglia dynamically interact with synapses in an activity-dependent manner (Biber et al., 2007; Kettenmann et al., 2013; Wake et al., 2013), to such as extent that the concept of a quad-partite synapse has been forwarded (Schafer et al., 2013). In fact, microglia are equipped with receptors for neurotransmitters (Pocock and Kettenmann, 2007), and excitatory transmission increases whereas inhibitory transmission decreases microglial processes dynamic (Fontainhas et al., 2011; Wong et al., 2011). Conversely, microglia can affect both excitatory and inhibitory transmission (Tsuda et al., 2003; Pascual et al., 2012) through the release of a variety of signals ranging from chemokines (Schafer et al., 2012), cytokines (Rebola et al., 2011), purines (Pascual et al., 2012; George et al., 2015), glutamate and D-serine (Scianni et al., 2013), NO (Zhan et al., 2014) or BDNF (Gomes et al., 2013; Parkhurst et al., 2013). The importance of this bi-directional communication between synapses and microglia is best heralded by the synaptic dysfunction observed upon genetic manipulation of microglia function (Roumier et al., 2004; Costello et al., 2011; Hoshiko et al., 2012), which can be direct or involve astrocytes (Pascual et al., 2012). Thus, microglia are critical for the dynamic synaptic carving that is essential to entrain adaptive brain function (Paolicelli et al., 2011; Ji et al., 2013; Cristovão et al., 2014; Zhan et al., 2014).

\section{DYSFUNCTION OF GLIAL CELLS AND DEPRESSION}

Numerous lines of evidence support the contention that a modification of astrocytes in frontolimbic regions is associated with depression (Altshuler et al., 2010; Rajkowska and Stockmeier, 2013; Peng et al., 2015). Most studies analyzing post-mortem brain samples from adult individuals with major 
depressive disorder or suicide completers concur to conclude that there is a decreased number of astrocytic-like elements in frontolimbic structures (Ongür et al., 1998; Rajkowska et al., 1999; Cotter et al., 2002; Medina et al., 2015; Nagy et al., 2015; Torres-Platas et al., 2015). This is paralleled by an alteration of astrocytic morphology, typified by hypertrophic cell bodies (Rajkowska et al., 1999; Cotter et al., 2002; Torres-Platas et al., 2011, 2015), and a modification in frontolimbic regions of the density of different astrocytic markers, such as GFAP (Miguel-Hidalgo et al., 2000; Si et al., 2004; Schlicht et al., 2007; Gittins and Harrison, 2011), connexins (Ernst et al., 2011; Sun et al., 2012; Miguel-Hidalgo et al., 2014), aquaporin-4 (Rajkowska et al., 2013), GLT-1 and glutamine synthase (Choudary et al., 2005; Sequeira et al., 2009; Miguel-Hidalgo et al., 2010) and an increased release of $\mathrm{S} 100 \beta$ (e.g., Grabe et al., 2001; Schroeter et al., 2008). A causal relation between astrocytic dysfunction and depression is provided by animal studies showing that the selective destruction of frontocortical astrocytes with the gliotoxin L- $\alpha$-aminoadipic acid is sufficient to trigger a depressive-like phenotype (Banasr and Duman, 2008); likewise, a depressive-like phenotype also emerges upon functional inhibition of astrocytes, such as upon downregulating synaptobrevin-2 thus blunting astrocytic vesicular release (Cao et al., 2013), upon altering connexin-mediated gap-junctions (Sun et al., 2012), upon knocking out IP3-receptor type-2 (Cao et al., 2013) or aquaporin-4 (Kong et al., 2014) or inhibiting astrocytic glutamate transporters (Bechtholt-Gompf et al., 2010; John et al., 2012). Notably, astrocytic function is affected by the signaling systems assumed as traditional culprits of depression, namely glucocorticoids (Yin et al., 2013), BDNF (Ye et al., 2011; Liu et al., 2015), serotonin (Hertz et al., 2015), noradrenaline (Madrigal et al., 2009; Pankratov and Lalo, 2015) or dopamine (Shao et al., 2013). Furthermore, treatments alleviating depressive symptoms can recover astrocytic function, such as SSRIs (Czéh et al., 2006; Schipke et al., 2011) or electroconvulsive shock (Iwata et al., 2011) and some are even critically dependent on astrocytic function, such as fluoxetine (Kong et al., 2009) or deep brain stimulation (Etiévant et al., 2015). Altogether, these observations indicate that a decreased astrocytic function in frontolimbic regions is necessary and sufficient for the emergence of depressive symptoms (Figure 1). This suggests a scenario where a defective astrocyte function

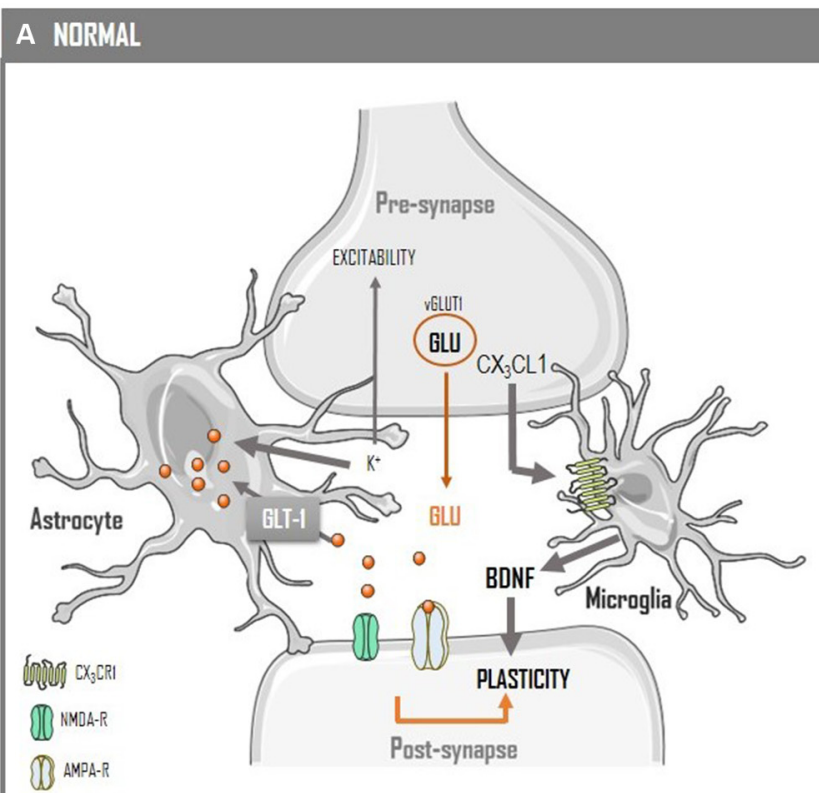

\section{B DEPRESSIDN}

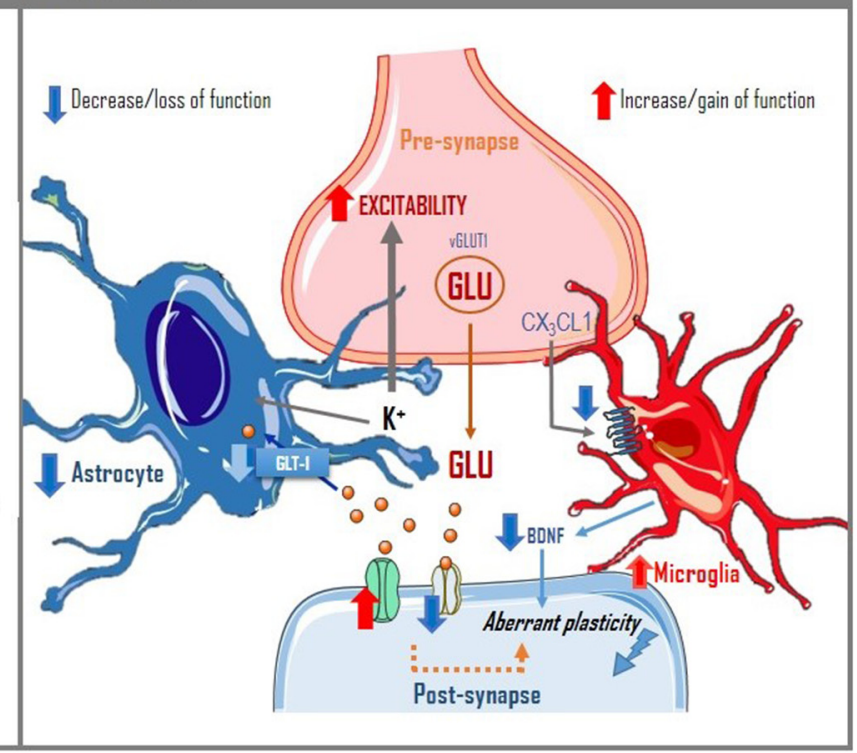

FIGURE 1 | Modifications of the quad-partite synapse in depression. The processing of information in synapses is not only defined by neurons, but also by glia cells, namely by astrocytes, which enwrap synapses, and microglia, which dynamically interact with synapses in an activity-dependent manner (A). Thus, amongst other roles, astrocytes regulate both $\mathrm{K}^{+}$and the basal levels of glutamate, defining the basal excitability of neurons; also the extracellular levels of glutamate contribute to define the density of NMDA and AMPA receptors in the plasma membrane of the post-synaptic compartment, which trigger and sustain alterations of synaptic plasticity, respectively. The excitability of neurons, their set-up of plasma membrane glutamate receptors, namely of NMDA receptors, and the neurotrophins support provided by glial cells are critical to allow the implementation of adequate synaptic plasticity traits, i.e., an appropriate encoding of both long-term potentiation (LTP) and depression (LTD) according to specific patterns of incoming information. In depression (B) there is a modification of information processing in excitatory synapses in frontolimbic area: there is modification of astrocytes, typified by hypertrophic cell bodies and decreased complexity and activity of phylopodia, resulting in an hypofunction of astrocytes and a decreased ability to buffer $\mathrm{K}^{+}$and to clear extracellular glutamate; this leads to increased excitability, corresponding to greater noise in the circuit, and to an imbalance of NMDA and AMPA receptors, with an increased availability of NMDA receptors in dendrites. Additionally, there is a decreased signaling through the master chemokine CX3CL1 in microglia, which is associated (through mechanisms still undefined) to a shift of microglia towards a more pro-inflammatory profile associated with decreased microglia-derived BDNF release. These alterations of the quad-partite synapse, typified by the altered inter-relations between glial cells and neurons, are associated with an aberrant plasticity, typified by a shift in the stimuli triggering LTD and LTP, which translates into inadequate encoding of information in frontocortical circuits. 
initially hampers synaptic plasticity, which then evolves into neuronal loss at advanced phases of depressive disorders.

Depression is also tightly associated with alterations of microglia and inflammation (Yirmiya et al., 2015; Figure 1). Thus, depressive patients exhibit increased levels of peripheral inflammatory markers (Raison et al., 2006; Howren et al., 2009); conversely, bolstering inflammation triggers a sickness behavior reminiscent of depression (Dantzer et al., 2008) and patients with inflammatory and autoimmune diseases often experience depression (Kiecolt-Glaser et al., 2015). Indeed, most studies converge to propose that microglia are morphologically altered in frontolimbic regions of depressed patients or suicide completers (Steiner et al., 2008; Schnieder et al., 2014; Torres-Platas et al., 2014; Setiawan et al., 2015). Likewise, repeated stress in rodents also triggers microglia dystrophy (Kreisel et al., 2014; Milior et al., 2015; Ślusarczyk et al., 2015) and the manipulation of microglia function, altering its dynamic (Kreisel et al., 2014) or hampering microglia-neuron communication via the CX3CR1-fractalkine pathway (Corona et al., 2010; Milior et al., 2015), alters stress responsiveness and depressive-like behavior. Furthermore, microglia function is affected by all the signaling systems traditionally associated with depression, namely glucocorticoids (Ros-Bernal et al., 2011), BDNF (Gomes et al., 2013), serotonin (Müller and Schwarz, 2007; Krabbe et al., 2012), noradrenaline or dopamine (Färber et al., 2005). Further highlighting the role of microglia in depression are the observations that antidepressants like ketamine (Walker et al., 2013), fluoxetine (Chung et al., 2011) or citalopram (Su et al., 2015) regulate microglia function and minocycline, an inhibitor of microglia, simultaneously recovers microglia function and emotional impairments (Hinwood et al., 2013). Thus, the available evidence indicates that microglia dysfunction is a core event in depression (Figure 1), affecting synaptic plasticity either directly (Paolicelli et al., 2011; Zhan et al., 2014) or indirectly through its ability to control astrocytic function (Pascual et al., 2012).

\section{INTEGRATIVE ROLE OF PURINES IN THE QUAD-PARTITE SYNAPSE TO CONTROL DEPRESSION}

In view of the key role of aberrant synaptic plasticity involving neuronal, astrocytic and microglia dysfunction (Figure 1), therapeutic strategies to manage depression should ideally target systems dedicated to the control of neuron-glia bidirectional communication. Purines operate one such system through the action of ATP and adenosine (Figure 2). ATP is released in a controlled manner from synaptic terminals, astrocytes and microglia and it is a documented signal to control astrogliosis, microglia dynamics and reactivity and synaptic transmission through ionotropic $\mathrm{P} 2 \mathrm{X} 1-7$ and metabotropic P2Y1-13 receptors (reviewed in Rodrigues et al., 2015). Adenosine can be formed from the catabolism of extracellular ATP (Augusto et al., 2013) by ectonucleotidases located in synapses (Cunha, 2001) or released as such through bidirectional nucleoside transporters in synapses (Pinto-Duarte et al., 2005). Adenosine mainly activates inhibitory $A_{1}$ and facilitatory $A_{2 A}$

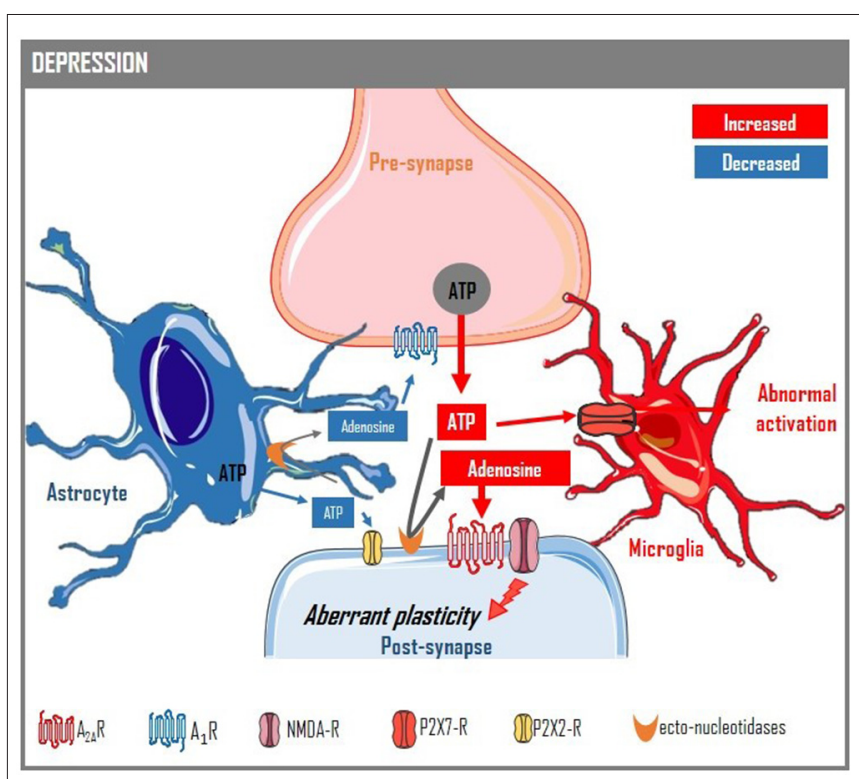

FIGURE 2 | Purine-based control of glia-neuron bidirectional communication in depression. Associated with astrocytic hypofunction in depression, there is a lower release of ATP and adenosine from astrocytes (Cao et al., 2013; Hines et al., 2013). This causes a deficient

astrocyte-to-neuron activation of P2X2 (ATP) receptors (Cao et al., 2013) and a deficient activation of inhibitory adenosine $A_{1}$ receptors in neurons (Serchov et al., 2015), which density decreases upon chronic stress (Cunha et al., 2006; Kaster et al., 2015). In parallel, there is an increased excitability (increased noise), which bolsters the synaptic release of ATP (Cunha et al., 1996), an up-regulation of synaptic adenosine $A_{2 A}$ receptors (Cunha et al., 2006; Batalha et al., 2013; Kaster et al., 2015), which is associated with aberrant plasticity (Li et al., 2015), and an up-regulation of microglia P2X7 receptors, which contributes to microglia hyper-responsiveness upon depression (Stokes et al., 2015). This illustrates the role of the purinergic system in the control of the homeostasis of the quad-partite synapse and shows that maladaptive changes in the purine neuromodulation system occur upon depression that can be exploited therapeutically, such as increasing the release of ATP and adenosine from astrocytes, decreasing the neuronal activation of $A_{2 A}$ receptor or bolstering the neuronal activation of $A_{1}$ receptors or inhibiting microglia P2X7 receptors.

receptors (Fredholm et al., 2005) that act neuronally to control synaptic transmission and plasticity (Cunha, 2008) and also control astrocytic (van Calker and Biber, 2005; Matos et al., 2013, 2015) and microglia function (Rebola et al., 2011; Luongo et al., 2014; George et al., 2015).

Notably, both ATP and adenosine signaling have been implicated in the control of depressive conditions (Figure 2). Thus, a deficient astrocyte-derived ATP release providing an insufficient $\mathrm{P} 2 \mathrm{X} 2$ receptor-mediated neuronal tonus was identified in chronically stressed mice (Cao et al., 2013); also, the prevention of excessive P2X7 receptor activation in glial cells ameliorates depressive-like conditions (Stokes et al., 2015) and P2X7 receptor polymorphisms lead to vulnerability to mood disorders (Bennett, 2007). The case for an involvement of adenosine is more robust. Thus, epidemiological studies show an inverse relation between the intake of moderate amounts of caffeine (an adenosine receptor antagonist) and the incidence of depression (Lucas et al., 2011) and suicide 
(Lucas et al., 2014). Accordingly, adenosine $\mathrm{A}_{2 \mathrm{~A}}$ receptors are up-regulated in animal models of chronic stress and polymorphisms of $\mathrm{A}_{2 \mathrm{~A}}$ receptors are associated with emotional disturbances (reviewed in Cunha et al., 2008), their overexpression triggers emotional dysfunction (Coelho et al., 2014) and their blockade prevents chronic stress-induced emotional dysfunction (Kaster et al., 2015). Additionally, there is a hypofunction of neuronal $A_{1}$ receptors due to decrease astrocyte-derived adenosine (Hines et al., 2013), which compensation with various antidepressant treatments can revert depressive-like behavior (Etiévant et al., 2015; Serchov et al., 2015).

This compilation of evidences illustrates the relevance of the purinergic signaling in the control of neuron-glia bidirectional communication and its therapeutic potential in the normalization of aberrant synaptic processing in frontolimbic circuits upon depression. Based on the available information,

\section{REFERENCES}

Achour, S., and Pascual, O. (2010). Glia: the many ways to modulate synaptic plasticity. Neurochem. Int. 57, 440-445. doi: 10.1016/j.neuint.2010. 02.013

Agostinho, P., Cunha, R. A., and Oliveira, C. (2010). Neuroinflammation, oxidative stress and the pathogenesis of Alzheimer's disease. Curr. Pharm. Des. 16, 2766-2778. doi: 10.2174/138161210793176572

Allen, N. J. (2014). Astrocyte regulation of synaptic behavior. Annu. Rev. Cell Dev. Biol. 30, 439-463. doi: 10.1146/annurev-cellbio-100913-013053

Altshuler, L. L., Abulseoud, O. A., Foland-Ross, L., Bartzokis, G., Chang, S., Mintz, J., et al. (2010). Amygdala astrocyte reduction in subjects with major depressive disorder but not bipolar disorder. Bipolar Disord. 12, 541-549. doi: 10.1111/j. 1399-5618.2010.00838.x

Araque, A., Carmignoto, G., Haydon, P. G., Oliet, S. H., Robitaille, R., and Volterra, A. (2014). Gliotransmitters travel in time and space. Neuron 81, 728-739. doi: 10.1016/j.neuron.2014.02.007

Araque, A., Parpura, V., Sanzgiri, R. P., and Haydon, P. G. (1999). Tripartite synapses: glia, the unacknowledged partner. Trends Neurosci. 22, 208-215. doi: 10.1016/s0166-2236(98)01349-6

Arnth-Jensen, N., Jabaudon, D., and Scanziani, M. (2002). Cooperation between independent hippocampal synapses is controlled by glutamate uptake. Nat. Neurosci. 5, 325-331. doi: 10.1038/nn825

Asztely, F., Erdemli, G., and Kullmann, D. M. (1997). Extrasynaptic glutamate spillover in the hippocampus: dependence on temperature and the role of active glutamate uptake. Neuron 18, 281-293. doi: 10.1016/s0896-6273(00) 80268-8

Augusto, E., Matos, M., Sévigny, J., El-Tayeb, A., Bynoe, M. S., Müller, C. E., et al. (2013). Ecto-5'-nucleotidase (CD73)-mediated formation of adenosine is critical for the striatal adenosine $\mathrm{A}_{2 \mathrm{~A}}$ receptor functions. J. Neurosci. 33, 11390-11399. doi: 10.1523/JNEUROSCI.5817-12.2013

Banasr, M., and Duman, R. S. (2008). Glial loss in the prefrontal cortex is sufficient to induce depressive-like behaviors. Biol. Psychiatry 64, 863-870. doi: 10.1016/j. biopsych.2008.06.008

Batalha, V. L., Pego, J. M., Fontinha, B. M., Costenla, A. R., Valadas, J. S., Baqi, Y., et al. (2013). Adenosine $A_{2 A}$ receptor blockade reverts hippocampal stress-induced deficits and restores corticosterone circadian oscillation. Mol. Psychiatry 18, 320-331. doi: $10.1038 / \mathrm{mp} .2012 .8$

Bechtholt-Gompf, A. J., Walther, H. V., Adams, M. A., Carlezon, W. A., Jr., Ongür, D., and Cohen, B. M. (2010). Blockade of astrocytic glutamate uptake in rats induces signs of anhedonia and impaired spatial memory. Neuropsychopharmacology 35, 2049-2059. doi: 10.1038/npp.2010.74

Bennett, M. R. (2007). Synaptic P2X7 receptor regenerative-loop hypothesis for depression. Aust. N Z J Psychiatry 41, 563-571. doi: 10. 1080/00048670701399994 the most promising strategy is a multi-target approach, based on the increase of astrocytic release of purines (both ATP and adenosine to activate $A_{1}$ receptors) coupled to antagonists of $\mathrm{P} 2 \mathrm{X} 7$ and of $\mathrm{A}_{2 \mathrm{~A}}$ receptors (Figure 2).

\section{AUTHOR CONTRIBUTIONS}

RAC planned and organized the review; all others contributed with valuable suggestions, partial writting and editing of the review.

\section{ACKNOWLEDGMENTS}

The research activity was supported by funding from NARSAD, Fundação para a Ciência e a Tecnologia (PTDC/NEUNMC/4154/2014, UID/NEU/04539/2013), COMPETE and FCT-CAPES.

Berman, R. M., Cappiello, A., Anand, A., Oren, D. A., Heninger, G. R., Charney, D. S., et al. (2000). Antidepressant effects of ketamine in depressed patients. Biol. Psychiatry 47, 351-354. doi: 10.1016/s0006-3223(99)00230-9

Berton, O., Hahn, C. G., and Thase, M. E. (2012). Are we getting closer to valid translational models for major depression? Science 338, 75-79. doi: 10 . 1126/science. 1222940

Bezzi, P., Gundersen, V., Galbete, J. L., Seifert, G., Steinhäuser, C., Pilati, E., et al. (2004). Astrocytes contain a vesicular compartment that is competent for regulated exocytosis of glutamate. Nat. Neurosci. 7, 613-620. doi: 10. $1038 / \mathrm{nn} 1246$

Biber, K., Neumann, H., Inoue, K., and Boddeke, H. W. (2007). Neuronal 'On' and 'Off signals control microglia. Trends Neurosci. 30, 596-602. doi: 10.1016/j.tins. 2007.08.007

Bushong, E. A., Martone, M. E., Jones, Y. Z., and Ellisman, M. H. (2002). Protoplasmic astrocytes in CA1 stratum radiatum occupy separate anatomical domains. J. Neurosci. 22, 183-192.

Cao, X., Li, L. P., Wang, Q., Wu, Q., Hu, H. H., Zhang, M., et al. (2013). Astrocytederived ATP modulates depressive-like behaviors. Nat. Med. 19, 773-777. doi: $10.1038 / \mathrm{nm} .3162$

Castrén, E. (2014). Neurotrophins and psychiatric disorders. Handb. Exp. Pharmacol. 220, 461-479. doi: 10.1007/978-3-642-45106-5_17

Cherry, J. D., Olschowka, J. A., and O'Banion, M. K. (2014). Are "resting" microglia more “m2”? Front. Immunol. 5:594. doi: 10.3389/fimmu.2014.00594

Choudary, P. V., Molnar, M., Evans, S. J., Tomita, H., Li, J. Z., Vawter, M. P., et al. (2005). Altered cortical glutamatergic and GABAergic signal transmission with glial involvement in depression. Proc. Natl. Acad. Sci. U S A 102, 15653-15658. doi: 10.1073/pnas.0507901102

Chung, Y. C., Kim, S. R., Park, J. Y., Chung, E. S., Park, K. W., Won, S. Y., et al. (2011). Fluoxetine prevents MPTP-induced loss of dopaminergic neurons by inhibiting microglial activation. Neuropharmacology 60, 963-974. doi: 10 . 1016/j.neuropharm.2011.01.043

Coelho, J. E., Alves, P., Canas, P. M., Valadas, J. S., Shmidt, T., Batalha, V. L., et al. (2014). Overexpression of adenosine $A_{2 A}$ receptors in rats: effects on depression, locomotion, and anxiety. Front. Psychiatry 5:67. doi: 10.3389/fpsyt. 2014.00067

Cornell-Bell, A. H., Finkbeiner, S. M., Cooper, M. S., and Smith, S. J. (1990). Glutamate induces calcium waves in cultured astrocytes: long-range glial signaling. Science 247, 470-473. doi: 10.1126/science.1967852

Corona, A. W., Huang, Y., O'Connor, J. C., Dantzer, R., Kelley, K. W., Popovich, P. G., et al. (2010). Fractalkine receptor (CX3CR1) deficiency sensitizes mice to the behavioral changes induced by lipopolysaccharide. J. Neuroinflammation 7:93. doi: 10.1186/1742-2094-7-93

Coryell, W., and Young, E. A. (2005). Clinical predictors of suicide in primary major depressive disorder. J. Clin. Psychiatry 66, 412-417. doi: 10.4088/jcp. v66n0401 
Costello, D. A., Lyons, A., Denieffe, S., Browne, T. C., Cox, F. F., and Lynch, M. A. (2011). Long-term potentiation is impaired in membrane glycoprotein CD200-deficient mice: a role for Toll-like receptor activation. J. Biol. Chem. 286, 34722-34732. doi: 10.1074/jbc.M111.280826

Cotter, D., Mackay, D., Chana, G., Beasley, C., Landau, S., and Everall, I. P. (2002). Reduced neuronal size and glial cell density in area 9 of the dorsolateral prefrontal cortex in subjects with major depressive disorder. Cereb. Cortex 12, 386-394. doi: 10.1093/cercor/12.4.386

Cristovão, G., Pinto, M. J., Cunha, R. A., Almeida, R. D., and Gomes, C. A. (2014). Activation of microglia bolsters synapse formation. Front. Cell. Neurosci. 8:153. doi: 10.3389/fncel.2014.00153

Crunelli, V., Carmignoto, G., and Steinhäuser, C. (2015). Novel astrocyte targets: new avenues for the therapeutic treatment of epilepsy. Neuroscientist 21, 62-83. doi: $10.1177 / 1073858414523320$

Cunha, R. A. (2001). Regulation of the ecto-nucleotidase pathway in rat hippocampal nerve terminals. Neurochem. Res. 26, 979-991. doi: 10.1046/j. 1471-4159.2000.0740334.x

Cunha, R. A. (2008). Different cellular sources and different roles of adenosine: $A_{1}$ receptor-mediated inhibition through astrocytic-driven volume transmission and synapse-restricted $\mathrm{A}_{2 \mathrm{~A}}$ receptor-mediated facilitation of plasticity. Neurochem. Int. 52, 65-72. doi: 10.1016/j.neuint.2007.06.026

Cunha, G. M., Canas, P. M., Oliveira, C. R., and Cunha, R. A. (2006). Increased density and synapto-protective effect of adenosine $\mathrm{A}_{2 \mathrm{~A}}$ receptors upon sub-chronic restraint stress. Neuroscience 141, 1775-1781. doi: 10.1016/j. neuroscience.2006.05.024

Cunha, R. A., Ferré, S., Vaugeois, J. M., and Chen, J. F. (2008). Potential therapeutic interest of adenosine $\mathrm{A}_{2 \mathrm{~A}}$ receptors in psychiatric disorders. Curr. Pharm. Des. 14, 1512-1524. doi: 10.2174/138161208784480090

Cunha, R. A., Vizi, E. S., Ribeiro, J. A., and Sebastião, A. M. (1996). Preferential release of ATP and its extracellular catabolism as a source of adenosine upon high- but not low-frequency stimulation of rat hippocampal slices. J. Neurochem. 67, 2180-2187. doi: 10.1046/j.1471-4159.1996.67052180.x

Czéh, B., Simon, M., Schmelting, B., Hiemke, C., and Fuchs, E. (2006). Astroglial plasticity in the hippocampus is affected by chronic psychosocial stress and concomitant fluoxetine treatment. Neuropsychopharmacology 31, 1616-1626. doi: 10.1038/sj.npp.1300982

Dantzer, R., O’Connor, J. C., Freund, G. G., Johnson, R. W., and Kelley, K. W. (2008). From inflammation to sickness and depression: when the immune system subjugates the brain. Nat. Rev. Neurosci. 9, 46-56. doi: 10.1038/nrn2297

Decrock, E., De Bock, M., Wang, N., Bultynck, G., Giaume, C., Naus, C. C., et al. (2015). Connexin and pannexin signaling pathways, an architectural blueprint for CNS physiology and pathology? Cell. Mol. Life Sci. 72, 2823-2851. doi: 10. 1007/s00018-015-1962-7

de Kloet, E. R., Joëls, M., and Holsboer, F. (2005). Stress and the brain: from adaptation to disease. Nat. Rev. Neurosci. 6, 463-475. doi: 10.1038/nrn1683

Diamond, J. S. (2001). Neuronal glutamate transporters limit activation of NMDA receptors by neurotransmitter spillover on CA1 pyramidal cells. J. Neurosci. 21, 8328-8338.

Duman, R. S., and Aghajanian, G. K. (2012). Synaptic dysfunction in depression: potential therapeutic targets. Science 338, 68-72. doi: 10.1126/science. 1222939

Duric, V., Banasr, M., Stockmeier, C. A., Simen, A. A., Newton, S. S., Overholser, J. C., et al. (2013). Altered expression of synapse and glutamate related genes in post-mortem hippocampus of depressed subjects. Int. J. Neuropsychopharmacol. 16, 69-82. doi: 10.1017/S1461145712000016

Ernst, C., Nagy, C., Kim, S., Yang, J. P., Deng, X., Hellstrom, I. C., et al. (2011). Dysfunction of astrocyte connexins 30 and 43 in dorsal lateral prefrontal cortex of suicide completers. Biol. Psychiatry 70, 312-319. doi: 10.1016/j.biopsych. 2011.03.038

Etiévant, A., Oosterhof, C., Bétry, C., Abrial, E., Novo-Perez, M., Rovera, R., et al. (2015). Astroglial control of the antidepressant-like effects of prefrontal cortex deep brain stimulation. EBioMedicine 2, 896-906. doi: 10.1016/j.ebiom.2015. 06.023

Färber, K., Pannasch, U., and Kettenmann, H. (2005). Dopamine and noradrenaline control distinct functions in rodent microglial cells. Mol. Cell. Neurosci. 29, 128-138. doi: 10.1016/j.mcn.2005.01.003

Fellin, T., Pascual, O., Gobbo, S., Pozzan, T., Haydon, P. G., and Carmignoto, G. (2004). Neuronal synchrony mediated by astrocytic glutamate through activation of extrasynaptic NMDA receptors. Neuron 43, 729-743. doi: 10 . 1016/j.neuron.2004.08.011

Ferrari, A. J., Charlson, F. J., Norman, R. E., Patten, S. B., Freedman, G., Murray, C. J., et al. (2013). Burden of depressive disorders by country, sex, age, and year: findings from the global burden of disease study 2010. PLoS Med. 10:e1001547. doi: 10.1371/journal.pmed.1001547

Feyissa, A. M., Chandran, A., Stockmeier, C. A., and Karolewicz, B. (2009). Reduced levels of NR2A and NR2B subunits of NMDA receptor and PSD-95 in the prefrontal cortex in major depression. Prog. Neuropsychopharmacol. Biol. Psychiatry 33, 70-75. doi: 10.1016/j.pnpbp.2008.10.005

Figley, C. R., and Stroman, P. W. (2011). The role(s) of astrocytes and astrocyte activity in neurometabolism, neurovascular coupling, and the production of functional neuroimaging signals. Eur. J. Neurosci. 33, 577-588. doi: 10.1111/j. 1460-9568.2010.07584.x

Fontainhas, A. M., Wang, M., Liang, K. J., Chen, S., Mettu, P., Damani, M., et al. (2011). Microglial morphology and dynamic behavior is regulated by ionotropic glutamatergic and GABAergic neurotransmission. PLoS One 6:e15973. doi: 10.1371/journal.pone.0015973

Fredholm, B. B., Chen, J. F., Cunha, R. A., Svenningsson, P., and Vaugeois, J. M. (2005). Adenosine and brain function. Int. Rev. Neurobiol. 63, 191-270. doi: 10. 1016/S0074-7742(05)63007-3

Genoud, C., Quairiaux, C., Steiner, P., Hirling, H., Welker, E., and Knott, G. W. (2006). Plasticity of astrocytic coverage and glutamate transporter expression in adult mouse cortex. PLoS Biol. 4:e343. doi: 10.1371/journal.pbio. 0040343

George, J., Gonçalves, F. Q., Cristóvão, G., Rodrigues, L., Meyer Fernandes, J. R., Gonçalves, T., et al. (2015). Different danger signals differently impact on microglial proliferation through alterations of ATP release and extracellular metabolism. Glia 63, 1636-1645. doi: 10.1002/glia.22833

Gilabert-Juan, J., Varea, E., Guirado, R., Blasco-Ibáñez, J. M., Crespo, C., and Nácher, J. (2012). Alterations in the expression of PSA-NCAM and synaptic proteins in the dorsolateral prefrontal cortex of psychiatric disorder patients. Neurosci. Lett. 530, 97-102. doi: 10.1016/j.neulet.2012.09.032

Gittins, R. A., and Harrison, P. J. (2011). A morphometric study of glia and neurons in the anterior cingulate cortex in mood disorder. J. Affect. Disord. 133, 328-332. doi: 10.1016/j.jad.2011.03.042

Gomes, C., Ferreira, R., George, J., Sanches, R., Rodrigues, D. I., Goncalves, N., et al. (2013). Activation of microglial cells triggers a release of brain-derived neurotrophic factor (BDNF) inducing their proliferation in an adenosine $\mathrm{A}_{2 \mathrm{~A}}$ receptor-dependent manner: $A_{2 A}$ receptor blockade prevents $B D N F$ release and proliferation of microglia. J. Neuroinflammation 10:16. doi: 10.1186/17422094-10-16

Grabe, H. J., Ahrens, N., Rose, H. J., Kessler, C., and Freyberger, H. J. (2001). Neurotrophic factor S100 beta in major depression. Neuropsychobiology 44 88-90. doi: 10.1159/000054922

Gray, J. D., Milner, T. A., and McEwen, B. S. (2013). Dynamic plasticity: the role of glucocorticoids, brain-derived neurotrophic factor and other trophic factors. Neuroscience 239, 214-227. doi: 10.1016/j.neuroscience.2012.08.034

Gyekis, J. P., Yu, W., Dong, S., Wang, H., Qian, J., Kota, P., et al. (2013). No association of genetic variants in BDNF with major depression: a meta- and gene-based analysis. Am. J. Med. Genet. B Neuropsychiatr. Genet. 162B, 61-70. doi: 10.1002/ajmg.b.32122

Haber, M., Zhou, L., and Murai, K. K. (2006). Cooperative astrocyte and dendritic spine dynamics at hippocampal excitatory synapses. J. Neurosci. 26, 8881-8891. doi: 10.1523/jneurosci.1302-06.2006

Halassa, M. M., Fellin, T., and Haydon, P. G. (2007). The tripartite synapse: roles for gliotransmission in health and disease. Trends Mol. Med. 13, 54-63. doi: 10 1016/j.molmed.2006.12.005

Halassa, M. M., Florian, C., Fellin, T., Munoz, J. R., Lee, S. Y., Abel, T., et al. (2009). Astrocytic modulation of sleep homeostasis and cognitive consequences of sleep loss. Neuron 61, 213-219. doi: 10.1016/j.neuron.2008. 11.024

Hanisch, U. K., and Kettenmann, H. (2007). Microglia: active sensor and versatile effector cells in the normal and pathologic brain. Nat. Neurosci. 10, 1387-1394. doi: $10.1038 / \mathrm{nn} 1997$

Haydon, P. G., and Carmignoto, G. (2006). Astrocyte control of synaptic transmission and neurovascular coupling. Physiol. Rev. 86, 1009-1031. doi: 10. 1152/physrev.00049.2005 
Henneberger, C., Papouin, T., Oliet, S. H., and Rusakov, D. A. (2010). Longterm potentiation depends on release of D-serine from astrocytes. Nature 463, 232-236. doi: 10.1038/nature08673

Hertz, L., Rothman, D. L., Li, B., and Peng, L. (2015). Chronic SSRI stimulation of astrocytic 5-HT2B receptors change multiple gene expressions/editings and metabolism of glutamate, glucose and glycogen: a potential paradigm shift. Front. Behav. Neurosci. 9:25. doi: 10.3389/fnbeh.2015.00025

Hines, D. J., Schmitt, L. I., Hines, R. M., Moss, S. J., and Haydon, P. G. (2013). Antidepressant effects of sleep deprivation require astrocyte-dependent adenosine mediated signaling. Transl. Psychiatry 3:e212. doi: 10.1038/tp. 2012.136

Hinwood, M., Tynan, R. J., Charnley, J. L., Beynon, S. B., Day, T. A., and Walker, F. R. (2013). Chronic stress induced remodeling of the prefrontal cortex: structural re-organization of microglia and the inhibitory effect of minocycline. Cereb. Cortex 23, 1784-1797. doi: 10.1093/cercor/bhs151

Hoshiko, M., Arnoux, I., Avignone, E., Yamamoto, N., and Audinat, E. (2012). Deficiency of the microglial receptor CX3CR1 impairs postnatal functional development of thalamocortical synapses in the barrel cortex. J. Neurosci. 32, 15106-15111. doi: 10.1523/JNEUROSCI.1167-12.2012

Howren, M. B., Lamkin, D. M., and Suls, J. (2009). Associations of depression with C-reactive protein, IL-1 and IL-6: a meta-analysis. Psychosom. Med. 71, 171-186. doi: 10.1097/PSY.0b013e3181907c1b

Iwata, M., Shirayama, Y., Ishida, H., Hazama, G. I., and Nakagome, K. (2011). Hippocampal astrocytes are necessary for antidepressant treatment of learned helplessness rats. Hippocampus 21, 877-884. doi: 10.1002/hipo.20803

Ji, K., Akgul, G., Wollmuth, L. P., and Tsirka, S. E. (2013). Microglia actively regulate the number of functional synapses. PLoS One 8:e56293. doi: 10 . 1371/journal.pone.0056293

John, C. S., Smith, K. L., Van't Veer, A., Gompf, H. S., Carlezon, W. A., Jr., Cohen, B. M., et al. (2012). Blockade of astrocytic glutamate uptake in the prefrontal cortex induces anhedonia. Neuropsychopharmacology 37, 2467-2475. doi: 10. 1038/npp.2012.105

Jourdain, P., Bergersen, L. H., Bhaukaurally, K., Bezzi, P., Santello, M., Domercq, M., et al. (2007). Glutamate exocytosis from astrocytes controls synaptic strength. Nat. Neurosci. 10, 331-339. doi: 10.1038/nn1849

Kang, H. J., Voleti, B., Hajszan, T., Rajkowska, G., Stockmeier, C. A., Licznerski, P., et al. (2012). Decreased expression of synapse-related genes and loss of synapses in major depressive disorder. Nat. Med. 18, 1413-1417. doi: 10.1038/nm. 2886

Kaster, M. P., Machado, N. J., Silva, H. B., Nunes, A., Ardais, A. P., Santana, M., et al. (2015). Caffeine acts through neuronal adenosine $A_{2 A}$ receptors to prevent mood and memory dysfunction triggered by chronic stress. Proc. Natl. Acad. Sci. U S A 112, 7833-7838. doi: 10.1073/pnas.1423088112

Kessler, R. C., Berglund, P., Demler, O., Jin, R., Koretz, D., Merikangas, K. R., et al. (2003). The epidemiology of major depressive disorder: results from the National Comorbidity Survey Replication (NCS-R). JAMA. 289, 3095-3105. doi: 10.1001/jama.289.23.3095

Kettenmann, H., Hanisch, U. K., Noda, M., and Verkhratsky, A. (2011). Physiology of microglia. Physiol. Rev. 91, 461-553. doi: 10.1152/physrev.00011.2010

Kettenmann, H., Kirchhoff, F., and Verkhratsky, A. (2013). Microglia: new roles for the synaptic stripper. Neuron 77, 10-18. doi: 10.1016/j.neuron.2012.12.023

Kiecolt-Glaser, J. K., Derry, H. M., and Fagundes, C. P. (2015). Inflammation: depression fans the flames and feasts on the heat. Am. J. Psychiatry 172, 1075-1091. doi: 10.1176/appi.ajp.2015.15020152

Koizumi, S., Fujishita, K., Tsuda, M., Shigemoto-Mogami, Y., and Inoue, K. (2003). Dynamic inhibition of excitatory synaptic transmission by astrocyte-derived ATP in hippocampal cultures. Proc. Natl. Acad. Sci. U S A 100, 11023-11028. doi: 10.1073/pnas.1834448100

Kong, H., Sha, L. L., Fan, Y., Xiao, M., Ding, J. H., Wu, J., et al. (2009). Requirement of AQP4 for antidepressive efficiency of fluoxetine: implication in adult hippocampal neurogenesis. Neuropsychopharmacology 34, 1263-1276. doi: $10.1038 / n p p .2008 .185$

Kong, H., Zeng, X. N., Fan, Y., Yuan, S. T., Ge, S., Xie, W. P., et al. (2014). Aquaporin-4 knockout exacerbates corticosterone-induced depression by inhibiting astrocyte function and hippocampal neurogenesis. CNS Neurosci. Ther. 20, 391-402. doi: 10.1111/cns.12222

Krabbe, G., Matyash, V., Pannasch, U., Mamer, L., Boddeke, H. W., and Kettenmann, H. (2012). Activation of serotonin receptors promotes microglial injury-induced motility but attenuates phagocytic activity. Brain Behav. Immun. 26, 419-428. doi: 10.1016/j.bbi.2011.12.002

Kreisel, T., Frank, M. G., Licht, T., Reshef, R., Ben-Menachem-Zidon, O., Baratta, M. V., et al. (2014). Dynamic microglial alterations underlie stress-induced depressive-like behavior and suppressed neurogenesis. Mol. Psychiatry 19, 699-709. doi: 10.1038/mp.2013.155

Krishnan, V., and Nestler, E. J. (2008). The molecular neurobiology of depression. Nature 455, 894-902. doi: 10.1038/nature07455

Lesch, K. P., and Waider, J. (2012). Serotonin in the modulation of neural plasticity and networks: implications for neurodevelopmental disorders. Neuron 76, 175-191. doi: 10.1016/j.neuron.2012.09.013

Li, N., Lee, B., Liu, R. J., Banasr, M., Dwyer, J. M., Iwata, M., et al. (2010). mTOR-dependent synapse formation underlies the rapid antidepressant effects of NMDA antagonists. Science 329, 959-964. doi: 10.1126/science.1190287

Li, N., Liu, R. J., Dwyer, J. M., Banasr, M., Lee, B., Son, H., et al. (2011). Glutamate $\mathrm{N}$-methyl-D-aspartate receptor antagonists rapidly reverse behavioral and synaptic deficits caused by chronic stress exposure. Biol. Psychiatry 69, 754-761. doi: 10.1016/j.biopsych.2010.12.015

Li, P., Rial, D., Canas, P. M., Yoo, J. H., Li, W., Zhou, X., et al. (2015). Optogenetic activation of intracellular adenosine $\mathrm{A}_{2 \mathrm{~A}}$ receptor signaling in the hippocampus is sufficient to trigger CREB phosphorylation and impair memory. Mol. Psychiatry 20, 1339-1349. doi: 10.1038/mp.2014.182

Lima, A., Sardinha, V. M., Oliveira, A. F., Reis, M., Mota, C., Silva, M. A., et al. (2014). Astrocyte pathology in the prefrontal cortex impairs the cognitive function of rats. Mol. Psychiatry 19, 834-841. doi: 10.1038/mp.2013.182

Liu, W. X., Wang, J., Xie, Z. M., Xu, N., Zhang, G. F., Jia, M., et al. (2015). Regulation of glutamate transporter 1 via BDNF-TrkB signaling plays a role in the anti-apoptotic and antidepressant effects of ketamine in chronic unpredictable stress model of depression. Psychopharmacology (Berl) doi: 10 1007/s00213-015-4128-2 [Epub ahead of print].

Lucas, M., Mirzaei, F., Pan, A., Okereke, O. I., Willett, W. C., O’Reilly, É. J., et al. (2011). Coffee, caffeine and risk of depression among women. Arch. Intern. Med. 171, 1571-1578. doi: 10.1001/archinternmed.2011.427

Lucas, M., O’Reilly, E. J., Pan, A., Mirzaei, F., Willett, W. C., Okereke, O. I., et al. (2014). Coffee, caffeine and risk of completed suicide: results from three prospective cohorts of American adults. World J. Biol. Psychiatry 15, 377-386. doi: 10.3109/15622975.2013.795243

Luongo, L., Guida, F., Imperatore, R., Napolitano, F., Gatta, L., Cristino, L., et al. (2014). The $A_{1}$ adenosine receptor as a new player in microglia physiology. Glia 62, 122-132. doi: 10.1002/glia.22592

Lynch, M. A. (2009). The multifaceted profile of activated microglia. Mol. Neurobiol. 40, 139-156. doi: 10.1007/s12035-009-8077-9

Machado-Vieira, R., Manji, H. K., and Zarate, C. A. (2009). The role of the tripartite glutamatergic synapse in the pathophysiology and therapeutics of mood disorders. Neuroscientist 15, 525-539. doi: 10.1177/1073858409336093

Madrigal, J. L., Leza, J. C., Polak, P., Kalinin, S., and Feinstein, D. L. (2009). Astrocyte-derived MCP-1 mediates neuroprotective effects of noradrenaline. J. Neurosci. 29, 263-267. doi: 10.1523/JNEUROSCI.4926-08.2009

Magariños, A. M., Verdugo, J. M., and McEwen, B. S. (1997). Chronic stress alters synaptic terminal structure in hippocampus. Proc. Natl. Acad. Sci. U S A 94, 14002-14008. doi: 10.1073/pnas.94.25.14002

Magistretti, P. J., Pellerin, L., Rothman, D. L., and Shulman, R. G. (1999). Energy on demand. Science 283, 496-497. doi: 10.1126/science.283.5401.496

Marzo, A., Bai, J., and Otani, S. (2009). Neuroplasticity regulation by noradrenaline in mammalian brain. Curr. Neuropharmacol. 7, 286-295. doi: 10. 2174/157015909790031193

Matos, M., Augusto, E., Agostinho, P., Cunha, R. A., and Chen, J. F. (2013). Antagonistic interaction between adenosine $A_{2 A}$ receptors and $\mathrm{Na}^{+} / \mathrm{K}^{+}$. ATPase- $\alpha 2$ controlling glutamate uptake in astrocytes. J. Neurosci. 33, 18492-18502. doi: 10.1523/JNEUROSCI.1828-13.2013

Matos, M., Shen, H. Y., Augusto, E., Wang, Y., Wei, C. J., Wang, Y. T., et al. (2015). Deletion of adenosine $A_{2 A}$ receptors from astrocytes disrupts glutamate homeostasis leading to psychomotor and cognitive impairment: relevance to schizophrenia. Biol. Psychiatry 78, 763-774. doi: 10.1016/j.biopsych.2015.02. 026

McEwen, B. S., Eiland, L., Hunter, R. G., and Miller, M. M. (2012). Stress and anxiety: structural plasticity and epigenetic regulation as a consequence of stress. Neuropharmacology 62, 3-12. doi: 10.1016/j.neuropharm.2011.07.014 
Medina, A., Watson, S. J., Bunney, W., Jr., Myers, R. M., Schatzberg, A., Barchas, J., et al. (2015). Evidence for alterations of the glial syncytial function in major depressive disorder. J. Psychiatr. Res. 72, 15-21. doi: 10.1016/j.jpsychires.2015. 10.010

Meyer, R. M., Burgos-Robles, A., Liu, E., Correia, S. S., and Goosens, K. A. (2014). A ghrelin-growth hormone axis drives stress-induced vulnerability to enhanced fear. Mol. Psychiatry 19, 1284-1294. doi: 10.1038/mp.2013.135

Miguel-Hidalgo, J. J., Baucom, C., Dilley, G., Overholser, J. C., Meltzer, H. Y., Stockmeier, C. A., et al. (2000). Glial fibrillary acidic protein immunoreactivity in the prefrontal cortex distinguishes younger from older adults in major depressive disorder. Biol. Psychiatry 48, 861-873. doi: 10 . 1016/s0006-3223(00)00999-9

Miguel-Hidalgo, J. J., Waltzer, R., Whittom, A. A., Austin, M. C., Rajkowska, G., and Stockmeier, C. A. (2010). Glial and glutamatergic markers in depression, alcoholism and their comorbidity. J. Affect. Disord. 127, 230-240. doi: 10.1016/j. jad.2010.06.003

Miguel-Hidalgo, J. J., Wilson, B. A., Hussain, S., Meshram, A., Rajkowska, G., and Stockmeier, C. A. (2014). Reduced connexin 43 immunolabeling in the orbitofrontal cortex in alcohol dependence and depression. J. Psychiatr. Res. 55, 101-109. doi: 10.1016/j.jpsychires.2014.04.007

Milior, G., Lecours, C., Samson, L., Bisht, K., Poggini, S., Pagani, F., et al. (2015). Fractalkine receptor deficiency impairs microglial and neuronal responsiveness to chronic stress. Brain Behav. Immun. doi: 10.1016/j.bbi.2015.07.024 [Epub ahead of print].

Müller, N., and Schwarz, M. J. (2007). The immune-mediated alteration of serotonin and glutamate: towards an integrated view of depression. Mol. Psychiatry 12, 988-1000. doi: 10.1038/sj.mp.4002006

Murphy-Royal, C., Dupuis, J. P., Varela, J. A., Panatier, A., Pinson, B., Baufreton, J., et al. (2015). Surface diffusion of astrocytic glutamate transporters shapes synaptic transmission. Nat. Neurosci. 18, 219-226. doi: 10.1038/nn.3901

Nagy, C., Suderman, M., Yang, J., Szyf, M., Mechawar, N., Ernst, C., et al. (2015). Astrocytic abnormalities and global DNA methylation patterns in depression and suicide. Mol. Psychiatry 20, 320-328. doi: 10.1038/mp.2014.21

Nedergaard, M. (1994). Direct signaling from astrocytes to neurons in cultures of mammalian brain cells. Science 263, 1768-1771. doi: 10.1126/science.8134839

Newman, E. A. (2003). Glial cell inhibition of neurons by release of ATP. J. Neurosci. 23, 1659-1666.

Oberheim, N. A., Wang, X., Goldman, S., and Nedergaard, M. (2006). Astrocytic complexity distinguishes the human brain. Trends Neurosci. 29, 547-553. doi: 10.1016/j.tins.2006.08.004

Ogata, K., and Kosaka, T. (2002). Structural and quantitative analysis of astrocytes in the mouse hippocampus. Neuroscience 113, 221-233. doi: 10.1016/s03064522(02)00041-6

Oliveira, J. F., Sardinha, V. M., Guerra-Gomes, S., Araque, A., and Sousa, N. (2015). Do stars govern our actions? Astrocyte involvement in rodent behavior. Trends Neurosci. 38, 535-549. doi: 10.1016/j.tins.2015.07.006

Omrani, A., Melone, M., Bellesi, M., Safiulina, V., Aida, T., Tanaka, K., et al. (2009). Up-regulation of GLT-1 severely impairs LTD at mossy fibre-CA3 synapses. J. Physiol. Lond. 587, 4575-4588. doi: 10.1113/jphysiol.2009.177881

Ongür, D., Drevets, W. C., and Price, J. L. (1998). Glial reduction in the subgenual prefrontal cortex in mood disorders. Proc. Natl. Acad. Sci. U S A 95, 13290-13295. doi: 10.1073/pnas.95.22.13290

Panatier, A., Theodosis, D. T., Mothet, J. P., Touquet, B., Pollegioni, L., Poulain, D. A., et al. (2006). Glia-derived D-serine controls NMDA receptor activity and synaptic memory. Cell 125, 775-784. doi: 10.1016/j.cell.2006.02.051

Pangrsic, T., Potokar, M., Stenovec, M., Kreft, M., Fabbretti, E., Nistri, A., et al. (2007). Exocytotic release of ATP from cultured astrocytes. J. Biol. Chem. 282, 28749-28758. doi: 10.1074/jbc.m700290200

Pankratov, Y., and Lalo, U. (2015). Role for astroglial $\alpha 1$-adrenoreceptors in gliotransmission and control of synaptic plasticity in the neocortex. Front. Cell. Neurosci. 9:230. doi: 10.3389/fncel.2015.00230

Paolicelli, R. C., Bolasco, G., Pagani, F., Maggi, L., Scianni, M., Panzanelli, P., et al. (2011). Synaptic pruning by microglia is necessary for normal brain development. Science 333, 1456-1458. doi: 10.1126/science.1202529

Parkhurst, C. N., Yang, G., Ninan, I., Savas, J. N., Yates, J. R., III, Lafaille, J. J., et al. (2013). Microglia promote learning-dependent synapse formation through brain-derived neurotrophic factor. Cell 155, 1596-1609. doi: 10.1016/j. cell.2013.11.030
Parpura, V., Basarsky, T. A., Liu, F., Jeftinija, K., Jeftinija, S., and Haydon, P. G. (1994). Glutamate-mediated astrocyte-neuron signalling. Nature 369, 744-747. doi: $10.1038 / 369744 \mathrm{a} 0$

Pascual, O., Ben Achour, S., Rostaing, P., Triller, A., and Bessis, A. (2012). Microglia activation triggers astrocyte-mediated modulation of excitatory neurotransmission. Proc. Natl. Acad. Sci. U S A 109, 197-205. doi: 10. 1073/pnas.1111098109

Pascual, O., Casper, K. B., Kubera, C., Zhang, J., Revilla-Sanchez, R., Sul, J. Y., et al. (2005). Astrocytic purinergic signaling coordinates synaptic networks. Science 310, 113-116. doi: 10.1126/science. 1116916

Pellerin, L., Bouzier-Sore, A. K., Aubert, A., Serres, S., Merle, M., Costalat, R., et al. (2007). Activity-dependent regulation of energy metabolism by astrocytes: an update. Glia 55, 1251-1262. doi: 10.1002/glia.20528

Peng, L., Verkhratsky, A., Gu, L., and Li, B. (2015). Targeting astrocytes in major depression. Expert. Rev. Neurother. 15, 1299-1306. doi: 10.1586/14737175. 2015.1095094

Perea, G., and Araque, A. (2007). Astrocytes potentiate transmitter release at single hippocampal synapses. Science 317, 1083-1086. doi: 10.1126/science.1144640

Perea, G., Yang, A., Boyden, E. S., and Sur, M. (2014). Optogenetic astrocyte activation modulates response selectivity of visual cortex neurons in vivo. Nat. Commun. 5:3262. doi: 10.1038/ncomms4262

Perry, V. H., and Gordon, S. (1988). Macrophages and microglia in the nervous system. Trends Neurosci. 11, 273-277. doi: 10.1016/0166-2236(88)90110-5

Petzold, G. C., Albeanu, D. F., Sato, T. F., and Murthy, V. N. (2008). Coupling of neural activity to blood flow in olfactory glomeruli is mediated by astrocytic pathways. Neuron 58, 897-910. doi: 10.1016/j.neuron.2008.04.029

Pilc, A., Wierońska, J. M., and Skolnick, P. (2013). Glutamate-based antidepressants: preclinical psychopharmacology. Biol. Psychiatry 73, 1125-1132. doi: 10.1016/j.biopsych.2013.01.021

Pinto-Duarte, A., Coelho, J. E., Cunha, R. A., Ribeiro, J. A., and Sebastião, A. M. (2005). Adenosine $A_{2 A}$ receptors control the extracellular levels of adenosine through modulation of nucleoside transporters activity in the rat hippocampus. J. Neurochem. 93, 595-604. doi: 10.1111/j.1471-4159.2005.03071.x

Pocock, J. M., and Kettenmann, H. (2007). Neurotransmitter receptors on microglia. Trends Neurosci. 30, 527-535. doi: 10.1016/j.tins.2007.07.007

Radley, J. J., Rocher, A. B., Miller, M., Janssen, W. G., Liston, C., Hof, P. R., et al. (2006). Repeated stress induces dendritic spine loss in the rat medial prefrontal cortex. Cereb. Cortex 16, 313-320. doi: 10.1093/cercor/bhi104

Raison, C. L., Capuron, L., and Miller, A. H. (2006). Cytokines sing the blues: inflammation and the pathogenesis of depression. Trends Immunol. 27, 24-31. doi: 10.1016/j.it.2005.11.006

Raivich, G. (2005). Like cops on the beat: the active role of resting microglia. Trends Neurosci. 28, 571-573. doi: 10.1016/j.tins.2005.09.001

Rajkowska, G., Hughes, J., Stockmeier, C. A., Javier Miguel-Hidalgo, J., and Maciag, D. (2013). Coverage of blood vessels by astrocytic endfeet is reduced in major depressive disorder. Biol. Psychiatry 73, 613-621. doi: 10.1016/j. biopsych.2012.09.024

Rajkowska, G., Miguel-Hidalgo, J. J., Wei, J., Dilley, G., Pittman, S. D., Meltzer, H. Y., et al. (1999). Morphometric evidence for neuronal and glial prefrontal cell pathology in major depression. Biol. Psychiatry 45, 1085-1098. doi: 10. 1016/s0006-3223(99)00041-4

Rajkowska, G., and Stockmeier, C. A. (2013). Astrocyte pathology in major depressive disorder: insights from human postmortem brain tissue. Curr. Drug Targets 14, 1225-1236. doi: 10.2174/13894501113149990156

Rebola, N., Simões, A. P., Canas, P. M., Tomé, A. R., Andrade, G. M., Barry, C. E., et al. (2011). Adenosine $A_{2 A}$ receptors control neuroinflammation and consequent hippocampal neuronal dysfunction. J. Neurochem. 117, 100-111. doi: 10.1111/j.1471-4159.2011.07178.x

Rodrigues, R. J., Tomé, A. R., and Cunha, R. A. (2015). ATP as a multi-target danger signal in the brain. Front. Neurosci. 9:148. doi: 10.3389/fnins.2015. 00148

Ros-Bernal, F., Hunot, S., Herrero, M. T., Parnadeau, S., Corvol, J. C., Lu, L., et al. (2011). Microglial glucocorticoid receptors play a pivotal role in regulating dopaminergic neurodegeneration in parkinsonism. Proc. Natl. Acad. Sci. U S A 108, 6632-6637. doi: 10.1073/pnas.1017820108

Rose, C. F., Verkhratsky, A., and Parpura, V. (2013). Astrocyte glutamine synthetase: pivotal in health and disease. Biochem. Soc. Trans. 41, 1518-1524. doi: 10.1042/BST20130237 
Rouach, N., Koulakoff, A., Abudara, V., Willecke, K., and Giaume, C. (2008). Astroglial metabolic networks sustain hippocampal synaptic transmission. Science 322, 1551-1555. doi: 10.1126/science.1164022

Roumier, A., Béchade, C., Poncer, J. C., Smalla, K. H., Tomasello, E., Vivier, E., et al. (2004). Impaired synaptic function in the microglial KARAP/DAP12deficient mouse. J. Neurosci. 24, 11421-11428. doi: 10.1523/jneurosci.2251-04. 2004

Sanacora, G., and Banasr, M. (2013). From pathophysiology to novel antidepressant drugs: glial contributions to the pathology and treatment of mood disorders. Biol. Psychiatry 73, 1172-1179. doi: 10.1016/j.biopsych.2013. 03.032

Schafer, D. P., Lehrman, E. K., Kautzman, A. G., Koyama, R., Mardinly, A. R., Yamasaki, R., et al. (2012). Microglia sculpt postnatal neural circuits in an activity and complement-dependent manner. Neuron 74, 691-705. doi: 10. 1016/j.neuron.2012.03.026

Schafer, D. P., Lehrman, E. K., and Stevens, B. (2013). The "quad-partite" synapse: microglia-synapse interactions in the developing and mature CNS. Glia 61, 24-36. doi: 10.1002/glia.22389

Schipke, C. G., Heuser, I., and Peters, O. (2011). Antidepressants act on glial cells: SSRIs and serotonin elicit astrocyte calcium signaling in the mouse prefrontal cortex. J. Psychiatr. Res. 45, 242-248. doi: 10.1016/j.jpsychires. 2010.06.005

Schlicht, K., Büttner, A., Siedler, F., Scheffer, B., Zill, P., Eisenmenger, W., et al. (2007). Comparative proteomic analysis with postmortem prefrontal cortex tissues of suicide victims versus controls. J. Psychiatr. Res. 41, 493-501. doi: 10. 1016/j.jpsychires.2006.04.006

Schnieder, T. P., Trencevska, I., Rosoklija, G., Stankov, A., Mann, J. J., Smiley, J., et al. (2014). Microglia of prefrontal white matter in suicide. J. Neuropathol. Exp. Neurol. 73, 880-890. doi: 10.1097/NEN.000000000 0000107

Schroeter, M. L., Abdul-Khaliq, H., Krebs, M., Diefenbacher, A., and Blasig, I. E. (2008). Serum markers support disease-specific glial pathology in major depression. J. Affect. Disord. 111, 271-280. doi: 10.1016/j.jad.2008. 03.005

Scianni, M., Antonilli, L., Chece, G., Cristalli, G., Di Castro, M. A., Limatola, C., et al. (2013). Fractalkine (CX3CL1) enhances hippocampal N-methyl-Daspartate receptor (NMDAR) function via D-serine and adenosine receptor type A2 (A2AR) activity. J. Neuroinflammation 10:108. doi: 10.1186/17422094-10-108

Sequeira, A., Mamdani, F., Ernst, C., Vawter, M. P., Bunney, W. E., Lebel, V., et al. (2009). Global brain gene expression analysis links glutamatergic and GABAergic alterations to suicide and major depression. PLoS One 4:e6585. doi: 10.1371/journal.pone.0006585

Serchov, T., Clement, H. W., Schwarz, M. K., Iasevoli, F., Tosh, D. K., Idzko, M., et al. (2015). Increased signaling via adenosine a1 receptors, sleep deprivation, imipramine and ketamine inhibit depressive-like behavior via induction of homerla. Neuron 87, 549-562. doi: 10.1016/j.neuron.2015. 07.010

Serrano, A., Haddjeri, N., Lacaille, J. C., and Robitaille, R. (2006). GABAergic network activation of glial cells underlies hippocampal heterosynaptic depression. J. Neurosci. 26, 5370-5382. doi: 10.1523/jneurosci.5255-05. 2006

Setiawan, E., Wilson, A. A., Mizrahi, R., Rusjan, P. M., Miler, L., Rajkowska, G., et al. (2015). Role of translocator protein density, a marker of neuroinflammation, in the brain during major depressive episodes. JAMA Psychiatry 72, 268-275. doi: 10.1001/jamapsychiatry.2014.2427

Shao, W., Zhang, S. Z., Tang, M., Zhang, X. H., Zhou, Z., Yin, Y. Q., et al. (2013). Suppression of neuroinflammation by astrocytic dopamine D2 receptors via $\alpha \mathrm{B}$-crystallin. Nature 494, 90-94. doi: 10.1038/nature 11748

Si, X., Miguel-Hidalgo, J. J., O’Dwyer, G., Stockmeier, C. A., and Rajkowska, G. (2004). Age-dependent reductions in the level of glial fibrillary acidic protein in the prefrontal cortex in major depression. Neuropsychopharmacology 29, 2088-2096. doi: 10.1038/sj.npp.1300525

Ślusarczyk, J., Trojan, E., Glombik, K., Budziszewska, B., Kubera, M., Lasoń, W., et al. (2015). Prenatal stress is a vulnerability factor for altered morphology and biological activity of microglia cells. Front. Cell. Neurosci. 9:82. doi: 10. 3389/fncel.2015.00082
Sousa, N., Cerqueira, J. J., and Almeida, O. F. (2008). Corticosteroid receptors and neuroplasticity. Brain Res. Rev. 57, 561-570. doi: 10.1016/j.brainresrev.2007. 06.007

Sousa, N., Lukoyanov, N. V., Madeira, M. D., Almeida, O. F., and PaulaBarbosa, M. M. (2000). Reorganization of the morphology of hippocampal neurites and synapses after stress-induced damage correlates with behavioral improvement. Neuroscience 97, 253-266. doi: 10.1016/s0306-4522(00) 00050-6

Steiner, J., Bielau, H., Brisch, R., Danos, P., Ullrich, O., Mawrin, C., et al. (2008). Immunological aspects in the neurobiology of suicide: elevated microglial density in schizophrenia and depression is associated with suicide. J. Psychiatr. Res. 42, 151-157. doi: 10.1016/j.jpsychires.2006.10.013

Stockmeier, C. A., Mahajan, G. J., Konick, L. C., Overholser, J. C., Jurjus, G. J., Meltzer, H. Y., et al. (2004). Cellular changes in the postmortem hippocampus in major depression. Biol. Psychiatry 56, 640-650. doi: 10.1016/j.biopsych.2004. 08.022

Stokes, L., Spencer, S. J., and Jenkins, T. A. (2015). Understanding the role of P2X7 in affective disorders-are glial cells the major players? Front. Cell. Neurosci. 9:258. doi: 10.3389/fncel.2015.00258

Su, F., Yi, H., Xu, L., and Zhang, Z. (2015). Fluoxetine and S-citalopram inhibit M1 activation and promote M2 activation of microglia in vitro. Neuroscience 294 60-68. doi: 10.1016/j.neuroscience.2015.02.028

Sun, J. D., Liu, Y., Yuan, Y. H., Li, J., and Chen, N. H. (2012). Gap junction dysfunction in the prefrontal cortex induces depressive-like behaviors in rats. Neuropsychopharmacology 37, 1305-1320. doi: 10.1038/npp. 2011.319

Suzuki, A., Stern, S. A., Bozdagi, O., Huntley, G. W., Walker, R. H., Magistretti, P. J., et al. (2011). Astrocyte-neuron lactate transport is required for long-term memory formation. Cell 144, 810-823. doi: 10.1016/j.cell.2011. 02.018

Theis, M., and Giaume, C. (2012). Connexin-based intercellular communication and astrocyte heterogeneity. Brain Res. 1487, 88-98. doi: 10.1016/j.brainres. 2012.06.045

Torres-Platas, S. G., Cruceanu, C., Chen, G. G., Turecki, G., and Mechawar, N. (2014). Evidence for increased microglial priming and macrophage recruitment in the dorsal anterior cingulate white matter of depressed suicides. Brain Behav. Immun. 42, 50-59. doi: 10.1016/j.bbi.2014. 05.007

Torres-Platas, S. G., Hercher, C., Davoli, M. A., Maussion, G., Labonté, B., Turecki, G., et al. (2011). Astrocytic hypertrophy in anterior cingulate white matter of depressed suicides. Neuropsychopharmacology 36, 2650-2658. doi: 10. 1038/npp.2011.154

Torres-Platas, S. G., Nagy, C., Wakid, M., Turecki, G., and Mechawar, N. (2015). Glial fibrillary acidic protein is differentially expressed across cortical and subcortical regions in healthy brains and downregulated in the thalamus and caudate nucleus of depressed suicides. Mol. Psychiatry doi: 10.1038/mp.2015. 65 [Epub ahead of print].

Trang, T., Beggs, S., and Salter, M. W. (2012). ATP receptors gate microglia signaling in neuropathic pain. Exp. Neurol. 234, 354-361. doi: 10.1016/j. expneurol.2011.11.012

Tritsch, N. X., and Sabatini, B. L. (2012). Dopaminergic modulation of synaptic transmission in cortex and striatum. Neuron 76, 33-50. doi: 10.1016/j.neuron. 2012.09.023

Tsuda, M., Shigemoto-Mogami, Y., Koizumi, S., Mizokoshi, A., Kohsaka, S., Salter, M. W., et al. (2003). P2X4 receptors induced in spinal microglia gate tactile allodynia after nerve injury. Nature 424, 778-783. doi: 10.1038/nature 01786

Tsvetkov, E., Shin, R. M., and Bolshakov, V. Y. (2004). Glutamate uptake determines pathway specificity of long-term potentiation in the neural circuitry of fear conditioning. Neuron 41, 139-151. doi: 10.1016/s0896-6273(03) 00800-6

Tzanoulinou, S., Riccio, O., de Boer, M. W., and Sandi, C. (2014). Peripubertal stress-induced behavioral changes are associated with altered expression of genes involved in excitation and inhibition in the amygdala. Transl. Psychiatry 4:e410. doi: 10.1038/tp.2014.54

van Calker, D., and Biber, K. (2005). The role of glial adenosine receptors in neural resilience and the neurobiology of mood disorders. Neurochem. Res. 30 , 1205-1217. doi: 10.1007/s11064-005-8792-1 
Verkhratsky, A., Steardo, L., Parpura, V., and Montana, V. (2015). Translational potential of astrocytes in brain disorders. Prog. Neurobiol. doi: 10.1016/j. pneurobio.2015.09.003 [Epub ahead of print].

Viswanathan, A., and Freeman, R. D. (2007). Neurometabolic coupling in cerebral cortex reflects synaptic more than spiking activity. Nat. Neurosci. 10, 1308-1312. doi: 10.1038/nn1977

Volterra, A., and Meldolesi, J. (2005). Astrocytes, from brain glue to communication elements: the revolution continues. Nat. Rev. Neurosci. 6, 626-640. doi: 10.1038/nrn1722

Wake, H., Moorhouse, A. J., Miyamoto, A., and Nabekura, J. (2013). Microglia: actively surveying and shaping neuronal circuit structure and function. Trends Neurosci. 36, 209-217. doi: 10.1016/j.tins.2012. 11.007

Walker, A. K., Budac, D. P., Bisulco, S., Lee, A. W., Smith, R. A., Beenders, B., et al. (2013). NMDA receptor blockade by ketamine abrogates lipopolysaccharideinduced depressive-like behavior in C57BL/6J mice. Neuropsychopharmacology 38, 1609-1616. doi: 10.1038/npp.2013.71

Wallraff, A., Köhling, R., Heinemann, U., Theis, M., Willecke, K., and Steinhäuser, C. (2006). The impact of astrocytic gap junctional coupling on potassium buffering in the hippocampus. J. Neurosci. 26, 5438-5447. doi: 10. 1523/jneurosci.0037-06.2006

Wallraff, A., Odermatt, B., Willecke, K., and Steinhäuser, C. (2004). Distinct types of astroglial cells in the hippocampus differ in gap junction coupling. Glia 48, 36-43. doi: 10.1002/glia.20040

Wong, W. T., Wang, M., and Li, W. (2011). Regulation of microglia by ionotropic glutamatergic and GABAergic neurotransmission. Neuron Glia Biol. 7, 41-46. doi: 10.1017/S1740925X11000123

Yang, Y., Ge, W., Chen, Y., Zhang, Z., Shen, W., Wu, C., et al. (2003). Contribution of astrocytes to hippocampal long-term potentiation through release of Dserine. Proc. Natl. Acad. Sci. U S A 100, 15194-15199. doi: 10.1073/pnas. 2431073100

Ye, Y., Wang, G., Wang, H., and Wang, X. (2011). Brain-derived neurotrophic factor (BDNF) infusion restored astrocytic plasticity in the hippocampus of a rat model of depression. Neurosci. Lett. 503, 15-19. doi: 10.1016/j.neulet.2011. 07.055
Yin, Y., Zhang, X., Li, Z., Deng, L., Jiao, G., Zhang, B., et al. (2013). Glucocorticoid receptor $\beta$ regulates injury-mediated astrocyte activation and contributes to glioma pathogenesis via modulation of $\beta$-catenin/TCF transcriptional activity. Neurobiol. Dis. 59, 165-176. doi: 10.1016/j.nbd.2013. 07.013

Yirmiya, R., Rimmerman, N., and Reshef, R. (2015). Depression as a microglial disease. Trends Neurosci. 38, 637-658. doi: 10.1016/j.tins.2015.08.001

Zarate, C. A., Jr., Singh, J. B., Carlson, P. J., Brutsche, N. E., Ameli, R., Luckenbaugh, D. A., et al. (2006). A randomized trial of an N-methylD-aspartate antagonist in treatment-resistant major depression. Arch. Gen. Psychiatry 63, 856-864. doi: 10.1001/archpsyc.63.8.856

Zhan, Y., Paolicelli, R. C., Sforazzini, F., Weinhard, L., Bolasco, G., Pagani, F., et al. (2014). Deficient neuron-microglia signaling results in impaired functional brain connectivity and social behavior. Nat. Neurosci. 17, 400-406. doi: 10. 1038/nn.3641

Zhang, J. M., Wang, H. K., Ye, C. Q., Ge, W., Chen, Y., Jiang, Z. L., et al. (2003). ATP released by astrocytes mediates glutamatergic activity-dependent heterosynaptic suppression. Neuron 40, 971-982. doi: 10.1016/s08966273(03)00717-7

Zhao, J., Bao, A. M., Qi, X. R., Kamphuis, W., Luchetti, S., Lou, J. S., et al. (2012). Gene expression of GABA and glutamate pathway markers in the prefrontal cortex of non-suicidal elderly depressed patients. J. Affect. Disord. 138, 494-502. doi: 10.1016/j.jad.2012.01.013

Conflict of Interest Statement: The authors declare that the research was conducted in the absence of any commercial or financial relationships that could be construed as a potential conflict of interest.

Copyright (C) 2016 Rial, Lemos, Pinheiro, Duarte, Gonçalves, Real, Prediger, Gonçalves, Gomes, Canas, Agostinho and Cunha. This is an open-access article distributed under the terms of the Creative Commons Attribution License (CC BY). The use, distribution and reproduction in other forums is permitted, provided the original author(s) or licensor are credited and that the original publication in this journal is cited, in accordance with accepted academic practice. No use, distribution or reproduction is permitted which does not comply with these terms. 